při výuce cizích jazyků v prostředí slovenské vysoké školy z pera E. Zelenické (Nitra).

Na konci našeho sdělení můžeme konstatovat, že rozhodnutí královéhradeckých kolegů vydávat pravidelné periodikum bylo správné, nebot' jejich pracoviště musí usilovat o odpovídající odbornost oborovou a zároveň využívat možností ke sdílení $\mathrm{z}$ praktických zkušeností z výuky ruského jazyka a ruské literatury $\mathrm{v}$ přípravě budoucích rusistů. K tomu si dovolujeme vznést malou poznámku: v podtitulu názvu časopisu by bylo vhodné upravit - Časopis pro ruskou filologii a výuku ruského jazyka a doplnit literatury.

Redakčnímu kolektivu přejeme hodně pracovních úspěchů, především dostatek přispěvovatelů a kvalitních př́íspěvků zaslaných $\mathrm{k}$ otištění.

Aleš Brandner

\title{
Bibliografie:
}

KOSTINCOVÁ, J. etc. (eds) (2020): Philogia Rossica. Časopis pro ruskou filologii a výuku ruského jazyka. 2020, č. 1.

\section{Sborník příspěvků z brněnského kolokvia k poctě prof. Stanislava Žaži}

GAZDA, J. (ed.): Př́spěvky k aktuálním otázkám jazykovědné rusistiky (5): pragmatika syntax - sémantika. Brno: Jan Sojnek - Galium, 2020. 127 s. ISBN 978-80-88296-o9-6.

Na jaře loňského roku se na Filozofické fakultě MU v Brně konalo jednodenní kolokvium Aktuální otázky současné jazykovědné rusistiky VI: pragmatika - syntaxsémantika. Bylo věnováno připomínce osobnosti předního brněnského rusisty a slavisty prof. PhDr. Stanislava Žaži, CSc., který by se v dubnu téhož roku dožil 90 let (zemřel 5. srpna 2018). Vzpomínkové setkání uspořádalo mateřské pracoviště pana profesora Ústav slavistiky FF MU spolu s Českou asociací slavistů a Středoevropským centrem slovanských studií a zúčastnili se ho kromě českých rusistů také hosté ze Slovenska a Ruska. Kolokvium bylo tematicky zaměřeno na oblasti, jimiž se prof. Žaža převážně zabýval. 
Obsah sborníku s názvem Př́spěvky k aktuálním otázkám jazykovědné rusistiky (5): pragmatika - syntax - sémantika tvoří studie, s nimiž účastníci na tomto kolokviu vystoupili a tematicky se vážou $\mathrm{k}$ daným oblastem. Sborník je v pořadí již pátým svazkem nepravidelné ediční řady, $\mathrm{v}$ níž jsou publikovány př́spěvky věnované připomínce životních jubileí významných představitelů brněnské jazykovědné rusistiky - prof. Stanislava Žaži, prof. Jiř́ho Jiráčka, doc. Aleše Brandnera.

Do recenzovaného svazku je zařazeno jedenáct př́spěvků. Jsou řazeny abecedně a v tomto pořadí je také zmiňujeme. Olga Lvovna Berger (FF MU, Brno) ve své studii Словосочетание и синтагма в русской и чешской грамматической традиции porovnává termíny словосочетание (slovní spojení) а синтагма (syntagma) na základě ruských a českých gramatik a učebnic větné skladby. Analyzuje obsah těchto termínů v pracích ruských, českých a slovenských rusistů i českých bohemistů, vymezuje základní problémy pro diskuzi o teorii slovního spojení a teorii syntagmatu a dochází k závěru, že rozdíly v objemu významu termínu словосочетание (slovní spojení) jsou podmíněny tím, zda jsou nebo nejsou do tohoto termínu zahrnuty syntaktické konstrukce vytvořené na základě predikace, koordinace, parataxe. Termín синтагма (syntagma) se podle zjištění autorky ve sledovaných jazycích liší sférou použití. Velmi aktuální a palčivé je téma př́íspěvku Jiřího Gazdy (FF MU, Brno) Skrytá aserce jako prostředek jazykové manipulace v současné ruské a české politické publicistice. Autor provádí diskurzivní analýzu titulků a perexů textů současné ruské a české politické publicistiky, v nichž je tvrzení a jeho záměna za předpoklad využíváno jako prostředek jazykové manipulace, a ukazuje, že skrytá aserce je spolu s nepřiměřeným používáním expresivního lexika a ironie jedním z rozpoznávacích znaků neautentické publicistiky a propagandy. Jedinou cestu, jak v populaci pěstovat kritické myšlení a s ním spjatou odolnost vůči jazykové manipulaci a propagandě, vidí autor v cílené systematické výchově k mediální gramotnosti. Lubomír Guzi (FF Prešovské univerzity, Prešov) v př́spěvku Проблематика видовременных форм русского глагола zkoumá aspektotemporální tvary ruského slovesa, sémantiku jimi vyjadřovaného děje a hledá invarianty obou členů binární vidové opozice. Konstatuje, že již dlouhou dobu má vedoucí roli v př́stupu k popisu vidu metoda interpretační a důležitou roli hraje také metoda kombinatorní. Ačkoli výzkum vidu ruského i slovanského slovesa má dlouholetou tradici a počet prací o něm v poslední době prudce vzrostl, v klíčových otázkách aspektologie podle zjištění autora stále přetrvávají podstatné rozpory, v pohledu na aspektotemporální tvary slovesa stále pokračuje „boj“ gramatiky se sémantikou v plánu výrazovém a v plánu obsahovém. Článek Ilony Janyškové (Ústav pro jazyk český AV ČR, Brno) Homonymie, nebo sémantická diferenciace? volně navazuje na dřivější studie autorky, které se zabývají několika česko-ruskými lexikálními paralelami. Tentokrát autorka pomocí etymologické analýzy řeší otázku, zda slovesa chytat (uchopovat, brát) a ruské nářeční xumamb 
(kývat, viklat, houpat, kolébat) vznikla sémantickou diferenciací ze společného praslovanského základu, nebo se jedná o geneticky nepř́ibuzná homonyma. Svojí analýzou ukazuje, že je obtížné jednoznačně rozhodnout, které řešení je správné. Ljuba Mrověcová (FF OU, Ostrava) navazuje na myšlenky prof. Žaži o významu a zastoupení latiny a řečtiny $\mathrm{v}$ moderních jazycích, především $\mathrm{v}$ jazycích slovanských, a předkládá př́spěvek s názvem Latinismy a grecismy $v$ terminologii managementu. Dokládá, že v manažerské komunikaci v současném českém i ruském podnikatelském prostředí má velké množství těchto termínů povahu internacionalismů s latinskými a řeckými kořeny a analyzuje vybrané frekventované internacionální termíny subjazyka managementu z hlediska etymologického, sémantického a morfologického. Př́spěvek Zdeňky Nedomové (FF OU, Ostrava) s názvem $K$ vyjadřování prostorových vztahů $v$ ruštině a češtině spadá do oblasti funkční gramatiky. Autorka v něm připomíná práce řady lingvistů a jejich pojetí prostorových vztahů v češtině, v ruštině i v konfrontaci s dalšími jazyky, především slovanskými. Zjištuje, že oblast vyjadřování prostorových vztahů je jako objekt lingvistického výzkumu velmi pestrá, $\mathrm{v}$ př́stupech jazykovědců $\mathrm{k}$ ní nachází průniky $\mathrm{i}$ inovativní pohledy a dokládá, že základními výrazovými prostředky jsou předložkové a bezpředložkové pády substantiv, adverbia, prefigovaná slovesa i frazeologické prostředky. Lukáš Plesník (FF OU, Ostrava), stejně jako L. Mrověcová, věnuje pozornost projevům vlivu latiny a řečtiny $\mathrm{v}$ současné ruštině, tentokrát $\mathrm{v}$ lingvistické terminologii. Ve své stati Греко-латинские терминоэлементы в лингвистической терминологии (на примере русского языка) zkoumá pozici internacionálního formantu ve struktuře termínu (prepozice, postpozice, interpozice), přičemž dochází $\mathrm{k}$ závěru, že převládají řecko-latinské komponenty $\mathrm{v}$ prepozici. Autor analyzuje internacionální formant také $\mathrm{z}$ hlediska jeho př́slušnosti k jazyku, který je donorem, a zjištuje, že nejčastěji lze řecko-latinské komponenty nalézt v prepozici. Ivo Pospíšil (FF MU, Brno) ve svém př́ispěvku s názvem fazyk a literatura: problém "nové filologie“ rekapituluje charakter brněnské lingvistické rusistiky a slavistiky, přičemž pozornost věnuje především osobnostem a přínosu Romana Mrázka a Stanislava Žaži. Dále autor představuje pohledy literárních vědců z několika zemí na problémy nové filologické jednoty nebo „nové filologie“ z úhlu filologického, ale i sociálněvědního a religiózního a pozornost věnuje také problémům terminologie. $Z$ jeho stati vyplývá závěr, že vznik nového filologického celku bude spíše pozvolným, dlouhým procesem nežli náhlým zrodem nové disciplíny. Galina Sergejevna Prokudina (FF MU, Brno) ve své studii Национальная специфика концепта «война» в русской когнитивной системе zkoumá koncept война (válka) v ruském kognitivním obrazu světa, a to na základě řetězového asociativního experimentu s tímto slovem jakožto stimulem. Jejího experimentu se zúčastnilo 100 respondentů - představitelů ruského národa různého pohlaví, věku, vzdělání a autorka na základě získaných asociativních reakcí zjištovala specifiku ve vnímání 
tohoto konceptu v ruském kognitivním obrazu světa. Stat Stanislava Alexandroviče Rylova (Ústav filologie a žurnalistiky, Univerzita Lobačevského, Nižnij Novgorod) Синтактический синкретизм как структурно-семантическая категория (на фоне сопоставительной славянской синтактологии) je př́spěvkem k bádání v oblasti lingvistického synkretismu. Autor definuje sémantické základy syntaktického synkretismu a vyčleňuje kategoriální příznaky v plánu obsahovém i v plánu výrazovém. Předmětem zkoumání jsou synkretické konstrukce v ruském a českém jazyce v pohledu diachronickém i synchronickém, prričemž základem pro porovnávání je plán výrazový. Celý sborník př́iznačně uzavírá stat Zdeňky Vychodilové (FF UP, Olomouc) s názvem Profesor Stanislav Žaža a česká a ruská syntaktická tradice. Předmětem tohoto príspěvku je přehled odlišností v chápání vybraných syntaktických jevů v ruské lingvistické tradici v porovnání s lingvistickou tradicí českou. Autorka se soustředuje na popis odlišností v pojetí větných členů a analyzuje doplněk, sémantický subjekt, objekt a přívlastek. Připomíná důsledný komparační a konfrontační přístup prof. Žaži ke zkoumaným jazykovým jevům a jeho prrínos mj. pro konstituování syntaktických teorií českých rusistů.

Sborník je důstojným připomenutím osobnosti profesora Stanislava Žaži, jeho prací, jeho odkazu. Ǩada př́spěvků na jeho bádání i prrímo navazuje. Uveřejněné stati nabízejí zajímavé podněty pro badatele v oblasti jazykovědné rusistiky a slavistiky a lze předpokládat, že se stanou inspirací pro další badatelskou činnost.

Marta Vágnerová

\section{Bibliografie:}

GAZDA, J. (ed.). (2020): Př́spěvky k aktuálním otázkám jazykovědné rusistiky (5): pragmatika - syntax - sémantika. Brno.

\section{Návraty k textologii a genezi textu}

ЩЕРБАКОВА, М.И. (ред.): От истории текста к истории литературы. Вып. 2. Москва: Институт мировой литературы им. А. М. Горького Российской академии наук, 2019. 408 с. ISBN 978-5-9208-0458-7.

V poslední době se objevila řadu náznaků i otevřených vyjádření vykazujících zjevné metodologicky podložené směřování $\mathrm{k}$ textologické a genetické analýze literárního textu. V širších souvislostech jsme se zmiňovali i o recenzované knize [POSPÍŠIL 